\title{
PENGARUH PEMBERIAN SEDIAAN MIKROEMULSI EKSTRAK DAUN KENIKIR (Cosmos caudatus) TERHADAP PENURUNAN KADAR ASAM URAT TIKUS YANG DI INDUKSI HATI AYAM
}

\author{
Muhammad Yusuf ${ }^{1}$, Poppy Dwi Citra Jaluri², Yogie Irawan ${ }^{3}$ \\ ${ }^{1,2,3}$ STIKes Borneo Cendekia Medika Pangkalan Bun \\ Email: stikesbcm15@gmail.com
}

\begin{abstract}
ABSTRAK
Hiperurisemia adalah keadaan dimana terjadi peningkatan kadar asam urat dalam darah diatas normal. Tanaman kenikir (Cosmos caudatus) merupakan tanaman yang banyak dijumpai di lingkungan sekitar, serta tanaman yang sudah tidak asing lagi dan telah banyak dikonsumsi sebagai sayuran. Salah satu kandungan dalam kenikir adalah senyawa golongan flavonoid. Pada penelitian ini mikroemulsi ekstrak kenikir digunakan untuk menurunkan kadar asam urat pada tikus yang diinduksi hati ayam. Mikroemulsi dibuat dengan menggunakan virgin coconut oil (VCO) sebagai fase minyak, Tween 80 dan Span 80 sebagai surfaktan dan gliserin sebagai kosurfaktan. Penelitian menggunakan 15 ekor tikus putih jantan galur wistar yang diinduksi jus hati ayam. Tikus dibagi menjadi 3 kelompok, yaitu kelompok kontrol negatif mikroemulsi placebo, kontrol positif mikroemulsi Allopurinol 3,6 mg/200 g BB tikus, serta kelompok perlakuan mikroemulsi daun kenikir $10 \mathrm{mg} / 200 \mathrm{~g}$ BB tikus yang diberikan secara peroral. Pengukuran kadar asam urat dilakukan pada hari ke-0 (kadar awal), hari ke-7 (kadar setelah induksi) dan hari ke-13(kadar setelah perlakuan). Persen penurunan kadar asam urat dalam darah dianalisis secara statistika dengan taraf kepercayaan 95\%. Hasil uji statistika menyatakan ada perbedaan antara kelompok kontrol negatif dan positif dengan kelompok perlakuan mikroemulsi daun kenikir memiliki nilai signifikansi 0,000. Sehingga mikroemulsi daun kenikir dapat menurunkan kadar urisemia tikus yang diinduksi ekstrak hati ayam namun memiliki kemampuan yang tidak sebaik mikroemulsi allopurinol.
\end{abstract}

Kata Kunci : Mikroemulsi, Kenikir (Cosmos Caudatus), Hiperurisemia, Ekstrak Hati Ayam, Allopurinol.

\section{ABSTRACT}

Hyperuricemia is an increase of blood Uric Acid level Beyonce the normal limit. In this study, the microemulsion of is used for decrease uric acid level rats induced by chicken's liver juice. Kenikir (Cosmos caudatus) is a plant that is often found in Environment, and already familiar for consumption as vegetable. One of content in kenikir is flavonoid. In The study kenikir herb microemultion for decreased of Uric Acid level in rats induced chicken's liver extract. A microemulsion was prepared using an oil phase of virgin coconut oil (VCO), a 
surfactant of tween 80 and span 80 and then a cosurfactant of gliserin. This study used 15 male rats of wistar stain induced chicken's liver juice. Rats were divided into 3 groups : negative control group placebo microemulsion, positive control group Allopurinol 3,6 mg/200 $\mathrm{g} \mathrm{BB}$, and 1 treatment group of kenikir microemulsion $10 \mathrm{mg} / 200 \mathrm{~g}$ BB yang were given orally. Measurement of uric acid performed on day 0 (initial level), day 7 (level after induction) and day 13 (level after treatment). Percent decrease in uric acid in the blood analyzed statistically with a 95\% confidence level. The results of the statistical test there is a difference between the negative and positif control with the group of kenikir microemulsion has significance value 0,000. The result, kenikir microemulsion shown to decrease uric acid levels rats induced by chicken's liver extract and it is not better than the positive control allopurinol.

Keywords : Microemulsion, Kenikir (Cosmos caudatus), Hyperuricemia, Chicken's liver extract, Allopurinol.

\section{PENDAHULUAN}

Lanjut usia dipandang sebagai masa degenerasi biologis yang disertai oleh berbagai penderitaan akibat berbagai macam penyakit yang menyertai proses menua. Namun merupakan tahap lanjut dari suatu proses kehidupan yang di tandai dengan penurunan kemampuan untuk tubuh beradaptasi dengan stres lingkungan. Pada umumnya tanda proses menua mulai tampak sejak usia 45 tahun dan akan menimbulkan masalah pada usia sekitar 60 tahun (Wardani, 2015).

Asam urat merupakan hasil metabolisme purin di dalam tubuh. Sebenarnya asam urat merupakan zat yang wajar di dalam tubuh namun menjadi tidak wajar ketika asam urat menjadi naik dan melebihi batas normal. Asam urat yang berlebihan tidak akan tertampung dan termetabolisme seluruhnya oleh tubuh, maka akan terjadi peningkatan kadar asam urat dalam darah yang disebut sebagai hiperurisemia (Wardani, 2015).

Tanaman kenikir (Cosmos caudatus) merupakan tanaman yang banyak dijumpai di lingkungan sekitar, serta tanaman yang sudah tidak asing lagi dan telah banyak dikonsumsi sebagai sayuran. Salah satu kandungan dalam kenikir adalah senyawa golongan flavonoid. Senyawa golongan flavonoid telah diketahui mempunyai efek antioksidan (Kurniasih, 2008). Daun kenikir (Cosmos caudatus) banyak dikonsumsi masyarakat sebagai sayuran. Secara tradisional daun ini juga digunakan sebagai obat penambah nafsu makan, lemah lambung, penguat tulang dan pengusir serangga. Daun Cosmos caudatus mengandung saponin, flavonoida polifenol dan minyak atsiri. flavonoid dapat berfungsi sebagai penurun kadar asam urat melalui penghambatan enzim xantin oksidase (Sunarni dkk, 2007).

Beberapa senyawa flavonoid yang memiliki aktivitas penghambatan xantin oksidase antara lain luteolin, apigenin, kaemferol, dan kuersetin. Pada penelitian ini digunakan hewan uji tikus yang diinduksi jus hati ayam dengan dosis $3 \mathrm{ml} / 200 \mathrm{~g}$ BB. Oleh karena itu pengobatan dengan daun kenikir diharapkan dapat menurunkan kadar 
asam urat. Penelitian perlu dilakukan untuk membuktikan peningkatan efektifitas pemberian mikroemulsi ekstrak daun kenikir terhadap penurunan kadar asam urat pada hewan uji tikus putih.

\section{METODE PENELITIAN \\ Pembuatan simplisia kenikir}

Kenikir yang diperoleh dari pasar tradisional di Pangkalan Bun, Kab. Kotawaringin Barat, Kalimantan Tengah kemudian dicuci hingga bersih lalu ditiriskan, lalu dirajang tipis-tipis, dikeringkan dengan cara diangin-anginkan, simplisia selanjutnya diblender dan dijadikan serbuk halus.

\section{Ekstraksi dan skrining fotokimia daun kenikir}

Serbuk Kenikir seberat 300 gram direndam dengan etanol $70 \%$ sebanyak 2L sambil diaduk perlahan hingga cairan penyari merendam diatas permukaan serbuk. Perendaman dilakukan selama 5 hari. Setelah 5 hari direndam, ampas diperas serta dilakukan penyaringan menggunakan kertas saring. Ekstrak dipisahkan untuk diuapkan menggunakan waterbath hingga eanol menguap tersisa $30 \%$ air dan ekstrak.

Skrining fitokimia dilakukan untuk mengetahui ada tidaknya komponen-komponen bioaktif yang terdapat pada daun kenikir. Skrining fitokimia meliputi uji alkaloid, flavonoid, saponin dan tanin dengan metode yang dikemukakan Harborne.

\section{Formulasi sediaan mikroemulsi} ekstrak daun kenikir

Formulasi mikroemulsi dibuat menjadi 3 formulasi F1 mengandung senyawa aktif ekstrak kenikir, F2 mengandung senyawa aktif allopurinol, dan F3 tidak memiliki senyawa aktif.

Tabel 1. Formula Mikroemulsi Ekstrak Kenikir

\begin{tabular}{ccccc}
\hline \multirow{2}{*}{$\begin{array}{c}\text { Nama } \\
\text { Bahan }\end{array}$} & \multicolumn{3}{c}{ Konsentrasi $\%$ v/v } & \multirow{2}{*}{ Fungsi } \\
\cline { 2 - 4 } VCO & 5 & 5 & 5 & Fase minyak \\
\hline Span 80 & 3,8 & 3,8 & 3,8 & Surfaktan \\
\hline Tween 80 & 16,2 & 16,2 & 16,2 & Surfaktan \\
\hline $\begin{array}{c}\text { Ekstrak } \\
\text { Kenikir }\end{array}$ & 10 & - & - & Zat Aktif \\
\hline Allopurinol & - & $360 *$ & - & Zat Aktif \\
\hline $\begin{array}{c}\text { Asam } \\
\text { Sitrat }\end{array}$ & 0,02 & 0,02 & 0,02 & Antioksidan \\
\hline $\begin{array}{c}\text { Buffer } \\
\text { Fosfat pH 7 }\end{array}$ & 2 & 2 & 2 & Pendapar \\
\hline Na Benzoat & 0,01 & 0,01 & 0,01 & Pengawet \\
\hline Gliserin & 20 & 20 & 20 & Kosurfaktan \\
\hline Akuades & $\begin{array}{c}\text { Add } \\
100\end{array}$ & $\begin{array}{c}\text { Add } \\
100\end{array}$ & $\begin{array}{c}\text { Add } \\
100\end{array}$ & Fase air \\
\hline & & & &
\end{tabular}

\section{Sumber : Data Primer}

Keterangan :

F1 : Formula Mikroemulsi Kenikir F2 : Formula Mikroemulsi Allopurinol

F3 : Formula Mikroemulsi Placebo *Allopurinol berarti 360 mg/100 ml

Teknik pembuatan mikroemulsi kenikir yaitu dengan mengecilkan ukuran partikel dan menghomogenkan dengan blender selama 5 menit, dilanjutkan dengan pengadukan dan pemanasan menggunakan hotplate magnetic stirrer memakai kecepatan sedang dan suhu $50^{\circ} \mathrm{C}$ selama 30 menit. Setelah itu dilanjutkan dengan pengadukan menggunakan ultra turrax dengan kecepatan 16000 rpm selama 10 menit (Ariviani, 2015).

\section{Uji sifat fisik sediaan mikroemulsi ekstrak daun kenikir}

- Uji Organoleptis

Pemeriksaan organoleptis ini dilakukan dengan cara mengamati 
bau, rasa, kejernihan, warna, homogenitas, dan pemisahan fase dari mikroemulsi ekstrak kenikir.

- $\quad$ Uji pH

Sediaan mikroemulsi diukur $\mathrm{pH}$ sediaan menggunakan kertas $\mathrm{pH}$ meter dengan membandingkan warna yang dihasilkan dengan warna $\mathrm{pH}$ yang tertera pada kemasan pada suhu $25 \pm 2^{\circ} \mathrm{C}$. (Athiyah, 2015).

- $\quad$ Uji Tipe Mikroemulsi

Pengujian dilakukan dengan cara mengencerkan mikroemulsi dengan air. Meneteskan air kedalam cawan yang berisi mikroemulsi. Jika mikroemulsi tercampur baik dengan air, maka tipe mikroemulsi adalah minyak dalam air atau o/w (oil/water), sebaliknya jika air yang ditambahkan membentuk globul pada mikroemulsi maka tipe mikroemulsi adalah air dalam minyak atau w/o (water/oil) (Martin et al, 2008).

- Uji Ukuran Partikel

Ukuran Partikel diukur menggunakan particle size analyzer dengan tipe dynamic light scattering. Sebanyak $10 \mathrm{ml}$ sampel diambil dan dimasukkan ke dalam kuvet. Kuvet harus terlebih dahulu dibersihkan sehingga tidak mempengaruhi hasil analisa. Kuvet yang telah diisi dengan sampel kemudian dimasukkan kedalam wadah sampel dan dilakukan analisa oleh alatnya (Horiba scientific, 2014).

- Penentuan Viskositas

Pengukuran

kekentalan mikroemulsi menggunakan partical size analyzer. Analisa dilakukan sama dengan saat pemeriksaan ukuran partikel .

- Uji Sentrifugasi

Sediaan mikroemulsi dimasukkan ke dalam tabung sentrifugasi kemudian dilakukan sentrifugasi pada kecepatan 3750 rpm selama 5 jam (Athiyah, 2015).

\section{Uji efektivitas penurunan kadar asam urat dengan sediaan mikroemulsi ekstrak daun kenikir terhadap hewan uji tikus yang diinduksi hati ayam}

- $\quad$ Perlakuan Hewan Uji

Sebelum diberi perlakuan, tikus (15 ekor) diadaptasikan dahulu dengan keadaan laboratorium selama 3 hari dengan memberikan pakan standar. Setelah diadaptasi pada hari selanjutnya (H0) maka dilakukan analisis kadar asam urat total terhadap semua hewan uji. Setelah diambil sampel darah dan diketahui kadar asam urat totalnya maka pada hari itu juga tikus diberi pakan tinggi asam urat agar kadar asam uratnya meningkat dilakukan selama 20 hari sebanyak 20 gram per tikus/hari. Pada hari ke 21 (H21) tikus diukur kadar asam uratnya totalnya kembali untuk mengetahui seberapa besar peningkatan kadar asam urat totalnya. Pada hari ke 21 - 28 tikus yang terdiri dari 3 kelompok. Kontrol positif, kontrol negatif dan kontrol perlakuan sediaan mikroemulsi daun kenikir.

Pada hari ke 28 (H28) semua hewan percobaan diambil darahnya kembali untuk mengetahui seberapa besar penurunannya. Darah diambil melalui vena mata selanjutnya darah didiamkan selama 15 menit, kemudian disentrifuge dengan kecepatan $3000 \mathrm{rpm}$ selama 15 menit, dan setelah terpisah maka serum diambil untuk dilakukan penetapan kadar asam urat totalnya 
dengan metode CHODPAP enzymatice photometric test.

\section{Analisis Data Uji Efektivitas}

Data hasil asam urat yang diperoleh. Kadar asam urat total ditentukan persen penurunannya untuk mengetahui efek dari mikroemulsi ekstrak daun kenikir. Data tersebut dianalisis untuk diuji normalitasnya dengan KolmogorovSmirnov z test $(p>0,05)$ dan Shapiro Wilk $(p>0,05)$. Uji homogenitas dengan Levene test $(p>0,05)$ untuk mengetahui data homogen atau tidak homogen. Uji parametrik menggunakan One way Anova dengan metode LSD untuk mengetahui perbedaan antar kelompok mikroemulsi daun kenikir, kelompok kontrol positif, dan kelompok kontrol negatif yang diberi perlakuan yang berbeda.

\section{HASIL DAN PEMBAHASAN}

Pembuatan Simplisia Kenikir (Cosmos caudatus)

Penelitian ini bertujuan untuk mengetahui efek pemberian mikroemulsi ekstrak daun kenikir (Cosmos caudatus) dalam menurunkan kadar asam urat sampel darah pada tikus putih yang diinduksi jus hati ayam. Herba kenikir diperoleh dari pasar tradisional di Pangkalan Bun, Kotawaringin Barat, Kalimantan Tengah.

Kenikir segar dikeringkan menjadi simplisia agar lebih tahan lama dan bebas dari jamur serta memudahkan dalam

penyimpanannya.

Proses pengolahannya dimulai dari sortasi basah yang bertujuan agar terpisah dari kotoran yang menempel di kenikir tersebut menggunakan air bersih yang mengalir, kemudian dirajang atau dipotong tipis-tipis menggunakan pisau, hal ini tujuannya selain untuk mempercepat pengeringan juga mempermudah pengubahan bentuk simplisia menjadi serbuk. Pengeringan dengan cara diangin-anginkan, gunanya agar senyawa aktif yang tidak tahan dengan sinar matahari tidak terdegradasi. Adanya sinar matahari akan merusak kandungan senyawa aktif flavonoidnya.

Simplisia kenikir yang sudah kering sempurna dihaluskan menggunakan blender. Ukuran serbuk yang kecil dapat mempercepat menembusnya cairan penyari ke dalam membran sel tanaman, selain itu ukuran serbuk yang kecil akan memperluas kontak antara serbuk dan cairan penyari. Serbuk kenikir kering diekstraksi dengan metode maserasi menggunakan pelarut etanol $70 \%$ karena tidak beracun untuk sediaan mikroemulsi peroral, serta flavonoid mudah larut dipelarut Polar. Alasan penggunaan metode maserasi karena metodenya sederhana dan dalam waktu yang singkat sudah dapat menyari ekstrak kenikir secara maksimal

Ekstrak etanol kenikir yang diperoleh dari hasil saringan serbuk seberat 300 gram dan direndam dalam etanol $70 \%$ sebanyak $2000 \mathrm{ml}$ adalah $1300 \mathrm{ml}$ ekstrak. Setelah itu ekstrak cair dipekatkan menggunakan waterbath. Penggunaan waterbath bertujuan untuk menguapkan etanol yang terkandung dalam ekstrak cair. Penguapan dilakukan hingga ekstrak berkurang $70 \%$ atau lebih. Ekstrak kental yang diperoleh setelah 
diuapkan \pm 8 jam sebanyak $335 \mathrm{ml}$. Sehingga dalam $335 \mathrm{ml}$ ekstrak kental mengandung 300 gram simplisia kenikir. Hasil ekstrak etanol $70 \%$ yang didapat kemudian dilakukan uji fitokimia ekstrak. Uji fitokimia ini bertujuan untuk mengetahui senyawa metabolit sekunder yang terkandung di dalam kenikir.

1. Uji Alkaloid : Sampel $+\mathrm{H}_{2} \mathrm{SO}_{4}$ 2N+pereaksi Dragendrorff $\rightarrow$ endapan cokelat

Sehingga kenikir positif mengandung alkaloid.

2. Uji Flavonoid : Sampel+serbuk $\mathrm{Zn}+\mathrm{HCl} 2 \mathrm{~N} \rightarrow$ Warna kuning, jingga sampai merah, Sehingga kenikir positif mengandung flavonoid

3. Uji Saponin : Sampel+air panas, dikocok $(+1$ tts $\mathrm{HCl} 1 \%) \rightarrow$ Terbentuk busa yang stabil, sehingga ekstrak kenikir positif mngandung saponin

4. Uji Tanin : Sampel+FeCl $31 \%$ $\rightarrow$ Terbentuk endapan hijau kecoklatan, sehingga kenikir positif mengandung tanin.

5. Uji steroid/terpenoid : Sampel+ kloroform+ As.asetat anhidrat+ $\mathrm{H}_{2} \mathrm{SO}_{4}$ pekat $\rightarrow$ warna biru menjadi hijau, sehingga ekstrak kenikir positif terpenoid dan steroid.

\section{Formulasi Sediaan Mikroemulsi Ekstrak Kenikir \\ Proses pembuatan mikroemulsi} dengan cara mencampurkan seluruh bahan kemudian diblender bertujuan untuk menghomogenkan dan memperkecil ukuran partikel, selain dihomogenkan menggunakan blender mikroemulsi juga dihomogenkan dengan menggunakan hotplate magnetic stirer, alat ini juga berfungsi sebagai pemanas, suhu yang digunakan $50^{\circ} \mathrm{C}$ bertujuan untuk mempercepat proses homogenisasi. Pengadukan menggunakan ultra turrax juga dilakukan pada kecepatan 16000 rpm selama 10 menit berfungsi untuk menghomogenkan mikroemulsi dan dapat mempengaruhi ukuran partikel sehingga bisa didaptkan ukuran yang mikron

Pada penelitian ini surfaktan yang digunakan adalah campuran tween 80 dan span 80 . Pencampuran dua jenis surfaktan berbeda nilai HLB ini bertujuan agar dapat berikatan dengan baik antara fase air dan fase minyak. HLB campuran yang diharapkan adalah 13, nilai HLB 13 termasuk ke dalam tipe mikroemulsi o/w sehingga cocok digunakan untuk peroral.

\section{Uji Sifat Fisik Mikroemulsi Ekstrak} Kenikir

Formula mikroemulsi kenikir akan diuji sediaan fisiknya. Sehingga mengetahui sediaan yang dibuat telah memenuhi standar sediaan yang baik. Meliputi uji organoleptis. Pengamatan organoleptis menunjukkan bahwa warna mikroemulsi kenikir yaitu bening, transparan dan hijau. Aromanya khas minyak kelapa yang sangat dominan karena tidak diberikan tambahan aroma lain yang dapat menutupi aroma minyak kelapa tersebut serta memiliki rasa agak sepat.

Uji pH bertujuan untuk mengetahui nilai $\mathrm{pH}$ mikroemulsi kenikir. Hasil pengukuran nilai $\mathrm{pH}$ adalah 5 tergolong dalam $\mathrm{pH}$ asam lemah. Hal ini memudahkan mikroemulsi kenikir terabsorbsi dengan cepat di lambung, karena $\mathrm{pH}$ 
lambung pada manusia cenderung asam maka lebih mudah menembus membran pada lambung.

Penentuan tipe mikroemulsi dilakukan dengan menggunakan metode pengenceran. Pada pengujian ini dihasilkan mikroemulsi dengan tipe minyak dalam air, karena air yang ditambahkan tercampur sempurna dengan mikroemulsi. Sehingga mikroemulsi kenikir tipe $\mathrm{m} / \mathrm{a}$ sudah sesuai untuk dijadikan sediaan peroral.

Uji viskositas digunakan untuk mengetahui nilai kekentalan medium pendispersi dari suatu sistem mikroemulsi. Semakin tinggi viskositas suatu mikroemulsi, semakin baik penghambatan agregasi atau penggabungan kembali globul sehingga mikroemulsi kenikir akan semakin stabil namun juga viskositas yang semakin tinggi akan membuat mikroemulsi kenikir sulit untuk mengalir keluar dari mulut botol. Nilai viskositas sebesar $0,895 \mathrm{mPa}$ `s menunjukkan mikroemulsi kenikir memiliki viskositas baik karena tidak terlalu kental dan tidak terlalu encer.

Ukuran partikel mikroemulsi kenikir adalah 1,6 $\mu \mathrm{m}$, hal ini sesuai dengan rentang ukuran mikroemulsi menurut Sinko yaitu antara 0,15-2 $\mu \mathrm{m}$. Ukuran partikel mikroemulsi yang kecil memudahkan senyawa aktif dari kenikir menembus membran melewati celah-celah membran dalam tubuh sehingga proses absorbsi senyawa aktif akan semakin cepat.

\section{Uji Efektivitas Antihiperurisemia Mikroemulsi Ekstrak Kenikir}

Pengujian efektivitas mikroemulsi kenikir dilakukan pada tikus hiperurisemia. Hiperurisemia adalah suatu kondisi dimana meningkatnya konsentrasi asam urat dalam darah yang melebihi nilai normal.

Hewan uji yang digunakan adalah tikus putih jantan galur Wistar berumur 4-5 bulan. Umur hewan uji 4-5 bulan merupakan tikus dewasa dimana metabolisme berjalan dengan optimal. Tikus yang digunakan berkelamin jantan agar tidak dipengaruhi fungsi hormonal yang dapat memengaruhi hasil penelitian. Tikus diadaptasi terlebih dahulu selama 7 hari sebelum diberi perlakuan untuk membiasakan hewan uji pada lingkungan yang baru, setelah diadaptasi 7 hari kemudian kadar asam urat diukur sebagai kadar normal dan sebagai dasar untuk mengetahui berhasil atau tidaknya induksi yang akan dilakukan. Pengkondisian tikus normal menjadi hiperurisemia digunakan jus hati ayam $3 \mathrm{ml}$ sehari agar kadar asam urat tikus dapat naik dengan cepat.

Pengambilan darah dilakukan sebelum induksi (H-0), setelah induksi (H-7) dan setelah perlakuan (H-13). Pengambilan darah sebelum induksi dilakukan sebagai kadar awal asam urat tikus sehat yang belum terpapar zat penginduksi. Pengambilan darah setelah diinduksi bertujuan untuk mengetahui induksi yang dilakukan berhasil atau tidak dengan membandingkan kadarnya dengan H-0. Darah diambil melalui vena mata tikus karena sampel yang dibutuhkan cukup besar dan kemungkinan terjadinya hemolisis kecil dibandingkan pengambilan melalui vena ekor. 


\begin{abstract}
Hewan uji yang telah dinyatakan hiperurisemia dikelompokan menjadi 3 kelompok yaitu kelompok kontrol negatif (mikroemulsi placebo), kelompok kontrol positif (mikroemulsi allopurinol 3,6 mg/200gBB), dan kelompok perlakuan menggunakan mikroemulsi kenikir $10 \mathrm{mg} / 200 \mathrm{gBB}$. Pemberian mikroemulsi kenikir, kontrol positif dan kontrol negatif dilakukan selama 7 hari dimulai dari hari ke-7 sampai hari ke-13. Selisih hasil pengukuran asam urat hari ke13 dan hari ke-7 adalah sebagai persen penurunan kadar asam urat tikus setelah perlakuan.
\end{abstract}

Berdasarkan diagram pada gambar 5.1 kadar asam urat pada semua kelompok mengalami kenaikan pada hari ke-7 dibandingkan hari ke-0 dan mengalami penurunan pada hari ke13 dibandingkan hari ke-7.

dan $\begin{array}{cr}\text { Pada kelompok kontrol positif } \\ \text { kelompok perlakuan }\end{array}$ mikroemulsi kenikir mengalami penurunan kadar asam urat berturutturut sebesar $41,71 \%$ dan $33,54 \%$ karena tikus yang hiperurisemia diobati dengan allopurinol pada kontrol positif dan kenikir pada kelompok perlakuan, sedangkan kontrol negatif terjadi penurunan kadar asam urat cuma $0,95 \%$.

Nilai persen penurunan kadar asam urat pada setiap kelompok perlakuan dilakukan uji statistika. Langkah awal dilakukan uji normalitas menggunakan metode Kolmogorov-Smirnov dan ShapiroWilk, data dikatakan normal apabila nilai $p>0,05$. Uji normalitas data dimaksudkan untuk memperlihatkan bahwa data sampel berasal dari populasi yang berdistribusi normal untuk persen penurunan pada kelompok perlakuan pemberian sediaan yang berbeda. Pada uji normalitas menggunakan uji Kolmogorov-Smirnov jika nilai signifikasi yang diperoleh lebih besar $p>0,05$, maka sampel berasal dari populasi yang berdistribusi normal, namun jika nilai signifikasi yang diperoleh lebih kecil $p<0,05$, maka sampel bukan berasal dari populasi yang berdistribusi normal. Berdasarkan tabel perhitungan uji Kolmogorov-Smirnov bahwa data persentase penurunan kadar asam urat pada kelompok pemberian mikroemulsi kenikir menghasilkan nilai signifikan $(0,200)$, sedangkan pada kelompok kontrol positif nilai signifikan $(0,139)$, dan pada kelompok kontrol negatif nilai signifikan $(0,156)$. Interpretasi data uji normalitas menunjukkan nilai signifikan semua kelompok $p>0,05$ yang berarti data berdistribusi normal.

\begin{tabular}{|c|c|c|}
\hline \multirow[t]{6}{*}{ Tabel 2} & Hasil & Pengukuran \\
\hline & Kadar & Urat \\
\hline & $(\mathrm{mg} / \mathrm{dl})$ & Persen \\
\hline & Kenaikan dan & Persen \\
\hline & Penurunan & Semua \\
\hline & Kelompok Perla & xuan \\
\hline
\end{tabular}


berdistribusi normal $(p>0,05)$ dan

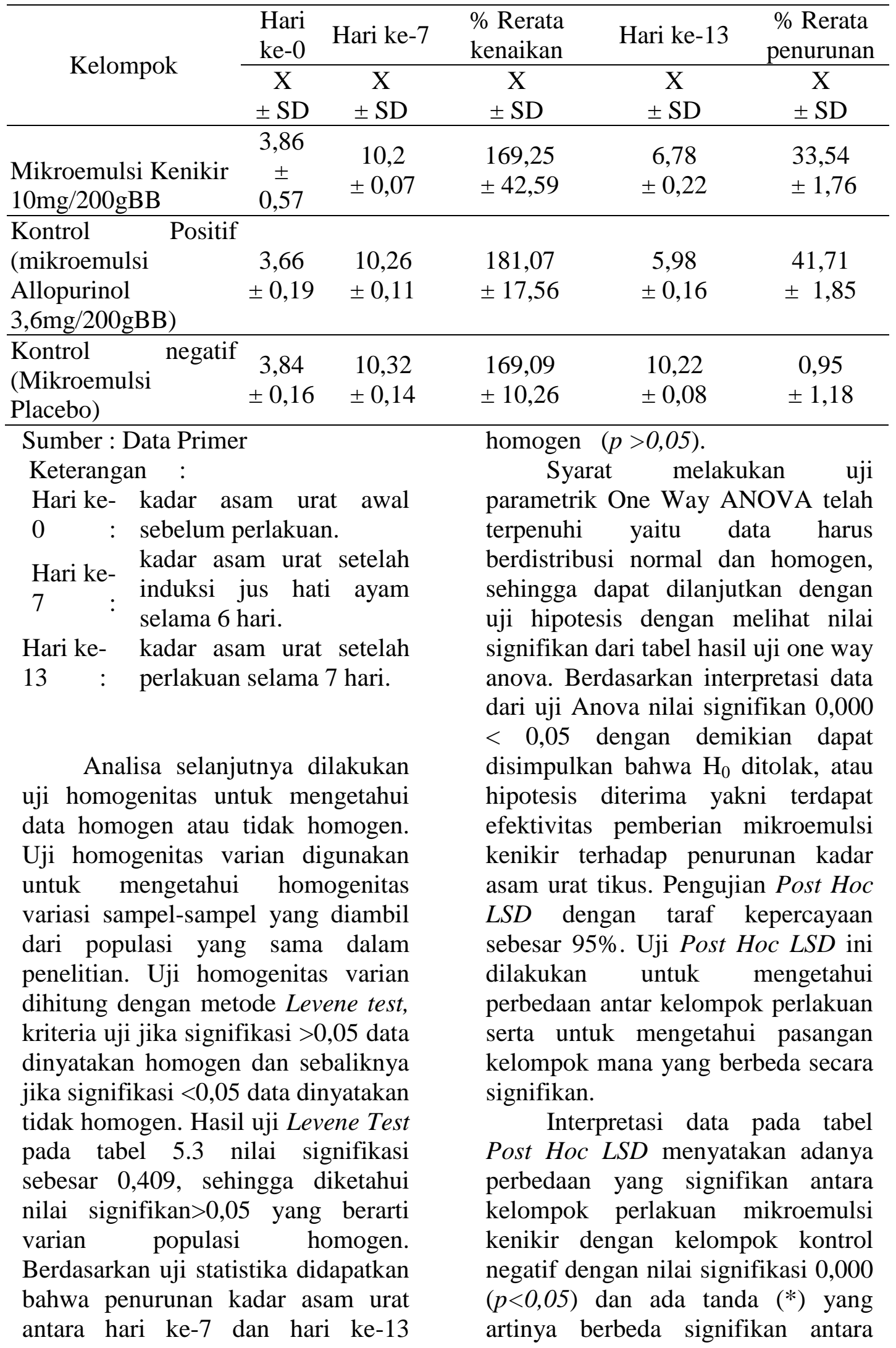


tikus yang diberi mikroemulsi placebo dengan tikus yang diberi mikroemulsi kenikir, serta ada perbedaan yang signifikan antara kelompok kontrol positif dengan mikroemulsi kenikir dengan nilai signifikan $0,000 \quad(p>0,05) \quad$ yang artinya mikroemulsi kenikir memiliki potensi untuk menurunkan kadar asam urat pada tikus hiperurisemia namun potensinya masih kurang dibandingkan dengan mikroemulsi allopurinol, sedangkan antara kelompok kontrol positif dan kontrol negatif ada perbedaan yang signifikan dengan nilai signifikan $0,000(p<0,05)$ serta ada tanda $(*)$ berarti adanya perbedaan signifikan antara tikus yang diberi obat asam urat (mikroemulsi allopurinol) dengan tikus yang tidak diberi obat penurun asam urat (mikroemulsi placebo).

Kontrol positif yang digunakan adalah mikroemulsi allopurinol dosis 3,6 mg/200gramBB tikus. Allopurinol merupakan suatu analog hipoxantin, dengan atom $\mathrm{N}$ dan $\mathrm{C}$ pada posisi 7 dan 8 saling bertukar, digunakan secara luas untuk mengatasi penyakit pirai. Mekanismenya adalah pada awalnya bertindak sebagai substrat kemudian sebagai inhibitor xantin oksidase. Oksidase tersebut akan menghidrolisasi allopurinol menjadi aloxantin (oksipurinol). Sintesis urat dari hipoxantin dan xantin segera menurun setelah pemberian allopurinol. Itu sebabnya konsentrasi hipoxantin dan xantin serum meningkat, sedangkan kadar asam urat menurun.

Mikroemulsi

Kenikir

mengandung berbagai bahan aktif, beberapa kandungan bahan aktif didalamnya diduga mampu menurunkan kadar asam urat dalam darah, seperti flavonoid dapat menurunkan kadar asam urat dengan cara menghambat kerja enzim xantin oksidasi sehingga pembentukan asam urat dapat dihambat.

Sediaan mikroemulsi kenikir sendiri dapat memudahkan kandungan bahan aktif dari ekstrak kenikirnya cepat terserap, karena mikroemulsi memiliki ukuran partikel yang kecil sehingga meningkatkan laju absorbsi dan meningkatkan proses pelarutan. Bahan aktif yang cepat terserap akan lebih cepat berperan dalam menurunkan kadar asam urat darah. Jadi, hasil penelitian menunjukkan bahwa pemberian mikroemulsi kenikir dengan dosis $10 \mathrm{mg} / 200 \mathrm{gBB}$ tikus dapat menurunkan kadar asam urat tikus yang diinduksi hati ayam.

\section{KESIMPULAN}

1. Ekstrak Kenikir positif mengandung senyawa metabolit meliputi flavonoid, alkaloid, tanin, saponin, steroid, dan terpenoid.

2. Mikroemulsi Kenikir yang terdiri dari campuran air, VCO sebagai fase minyak, tween 80 dan span 80 sebagai surfaktan, serta gliserin sebagai cosurfaktan mampu menghasilkan mikroemulsi yang jernih, transparan, stabil dan memiliki ukuran partikel mikron yaitu $1,6 \mu \mathrm{m}$.

3. Pemberian mikroemulsi ekstrak kenikir sebanyak 10 $\mathrm{mg} / 200 \mathrm{gBB}$ dapat menurunkan kadar asam urat pada tikus yang diinduksi jus hati ayam. 


\section{SARAN}

1. Perlu dilakukan penelitian lebih lanjut tentang proses mekanisme kerja obat dari mikroemulsi kenikir untuk pengobatan hiperurisemia.

2. Perlu dilakukan uji toksisitas pada mikroemulsi daun kenikir.

3. Perlu dilakukan penelitian lebih lanjut dengan membuat sediaan dalam bentuk nanoemulsi kenikir untuk meningkatkan efektivitas dalam menurunkan kadar asam urat.

\section{DAFTAR PUSTAKA}

Adib, M. 2009. Kupas Tuntas Asam urat. Yogyakarta : Dianloka Pustaka Populer.

Ariviani, S., Raharjo, S., Anggrahini, S., dan Naruki, S. 2015. Formulasi Dan Stabilitas Mikroemulsi O/W Dengan Metode Emulsifikasi Spontan Menggunakan VCO Dan Minyak Sawit Sebagai Fase Minyak: Pengaruh Rasio Surfaktan-Minyak. Jurnal Agritech, Vol. 35, No. 1, 2734.

Athiyah. 2015. Formulasi Dan Evaluasi Fisik Mikroemulsi Yang Mengandung Ekstrak Umbi Talas (Colocasia esculenta (L.) Schoot var antiquorum) sebagai antiaging. Skripsi. Fakultas kedokteran dan ilmu kesehatan prodi farmasi UIN Syarif Hidayatullah Jakarta.

Gani, N., Momuat, L.I., Pitoi, M.M. 2013. Profil Lipida Plasma Tikus Wistar yang Hiperkolesterolemia pada Pemberian Gedi Merah (Abelmoschus manihot L.). Jurnal MIPA UNSTRAT. No. 2 (1) hlm. 44-49.

Horiba Scientific. 2014. A Guidebook to Partical Size Anaysis.

Martin, Alfred. 2008. Farmasi Fisika Dasar-Dasar Farmasi Fisik dalam Ilmu Farmasetik Ed. Ketiga jilid 2. Jakarta : UI Press.

Moghimipour, E., Salimi, A., dan Leis, F. 2012. Preparation dan Evaluation of Tretinoin Microemulsion Based on Pseudo-Ternary Phase Diagram. Advanced Pharmaceutical Bulletin, 2(2), pp. 141-147.

Tatto, Dermiati., Dewi, N.P., Tibe, F. 2017. Efek Antihiperkolesterol dan Antihiperhgikemik Ekstrak Daun Ceremai (Phyllantus acidus (L.) Skeels) padaTikus Putih Jantan (Rattus norvegicus) Hiperkolesterol Diabetes. Jurnal Farmasi Galenika. Vol. 3 (2) Hlm : 157-164. STIFAR Pelita Mas Palu. 